Cowley, P. (2016). Declining the Interpreter's Role in World War I. Linguistica Antverpiensia, New Series: Themes in Translation Studies, 15, 72-88

\title{
Declining the interpreter's role in World War I
}

\section{Peter Cowley}

University of Queensland, Australia

p.cowley1@uq.edu.au

In this article I will examine autobiographical and fictionalised accounts of World War One by three French interpreters: the writer André Maurois, the painter Paul Maze, and the cartoonist Hansi. All three worked as officiers de liaison with the British Expeditionary Force, discharging their duties in remarkably divergent ways and accounting for them equally differently. My focus will be on how their accounts can be read as representations of the role of the interpreter, and at the same time how the figure of the interpreter, underpinned by the assumption of neutrality, is deployed to represent other activities in conflict zones.

\section{Preamble}

Centenary celebrations invite reflection, and sometimes even comparison. We are tempted to measure ourselves against the past, and evaluate the progress we have made - or the extent of our diminishment. In the context of a larger project exploring representations of translators and interpreters in generically disparate contexts, I take the centenary of World War One as an opportune moment to explore the figure and figurative power of the interpreter during that conflict. My specific focus in this article will be three French interpreters, by which I mean enlisted officers with advanced language skills assigned as officiers de liaison, one of whose primary tasks was interpreting. Then, as now, the task of interpreting in a military conflict was embedded in a range of other duties, all of which were subordinate to hierarchical command structures. ${ }^{1}$ The accounts I will examine here are unified by historical moment, yet are generically quite heterogeneous. Therefore my analysis will not be concerned with questions of generic conformity, but must find another point of comparison. That point is the common trope of regret at being segregated from combat, which can be found in each of the texts under consideration. While this trope plays out differently in each account, in each it can be read as a prism that crystallises different representations of the interpreter in the Great War. 


\section{Regret}

There are three notable, extended accounts of the Great War by French interpreters: that of the previously mentioned Hansi; a memoir by Paul Maze; and a novel (and memoir) by André Maurois. On the basis of their bilingualism all three served as French officiers de liaison, and thus as interpreters, with the British Expeditionary Force in France. All three were either artistically or intellectually inclined. Hansi's $A$ travers les lignes ennemies. Trois années d'offensive contre le moral allemand [Across Enemy Lines. A Three-Year Offensive against German Morale] is a surprising and fascinating documentary account, to which we shall come last. The Impressionist painter Paul Maze gives us a more businesslike memoir, A Frenchman in Khaki, to which his friend Winston Churchill wrote the preface. It is a blow-by-blow narrative, overburdened by the details of this battle, that manoeuvre, madame $\mathrm{X}$ who found them fresh eggs for breakfast to the delight of the general, and so on - but not without interest.

And there is Émile Salomon Wilhelm Herzog, whom we know better as André Maurois, but who was not yet Maurois, nor really a writer, when he left for the front. Yet it was the war that made him both of those things. Maurois recounts this experience in his Mémoires and not one but two novels. ${ }^{2}$ They are Les Silences du Colonel Bramble (1918), written at the front, and Les Discours du Docteur O'Grady (1922), its somewhat belated sequel. ${ }^{3}$ Of the two novels I will concern myself primarily with Les Silences du Colonel Bramble - a fictionalised and contemporaneous account of his time at the front - but will read it in tandem with Maurois' Mémoires, which describes his adolescent experience of learning English and his intercultural experiences in London; then his entry into the army and secondment to the British Expeditionary Force, and indeed the circumstances of the writing of Bramble. It is from the Mémoires that I take my cue. The beginning of the Grande Guerre episode - when he is enrolled as an officier de liaison without his knowledge, by a gendarme who knocks on his mother's door to enquire whether young Herzog speaks English - is marked by these repeated assertions of regret:

Mais, mon capitaine, dis-je, j'aime mieux partir avec les autres; je veux faire la guerre. (Maurois, 1970a, p. 115)

'But, mon Capitaine', I said, 'I should prefer to go with the others; I want to see action.' (Maurois, 1970b, p. 95)

[Janine] avait embrassé avec passion, avant le départ du train, un guerrier; elle se retrouvait, sur le quai de la gare, avec un petit fonctionnaire. Je sentais ce contraste et j'en souffrais (Maurois, 1970a, p. 116). 
At parting [Janine, his wife] had passionately embraced a warrior. What she recovered on the station platform was an unimportant functionary. I felt this contrast, and I suffered from it. (Maurois, 1970b, p. 96)

J'étais parti pour commander une section, pour manœuvrer et tirer, pour risquer ma vie. Mon désir de sacrifice avait frappé dans le vide et j'avais perdu l'équilibre. (Maurois, 1970a, p. 118)

I had left Elbeuf to take command of a section, to manoeuvre and shoot, to risk my life. My desire for sacrifice had been denied and I had lost my equilibrium. (Maurois, 1970b, p. 98)

And the most succinct formulation:

Je souffrais de faire ce métier quand mes amis étaient au feu. (Maurois, 1970a, p. 118)

But I suffered from carrying on this overseer's task while my friends were under fire. (Maurois, 1970b, p. 98)

Paul Maze expresses similar sentiments, which are sublimated as a conflict within:

Not liable to be called up with the colours, as I had not been passed fit for military service at the age of twenty-one, I felt out of it all; a conflict was rising within me - I had to do something. (Maze, 1934, p. 6)

And so do Hansi and Tonnelat (1922), albeit less ardently than either Maze or Maurois:

J'ai dû, avec regret, abandonner la capote du simple soldat, et je menais à Epinal la vie un peu désœuvrée d'interprète de la place. (Hansi \& Tonnelat, 1922, p. 7)

With regret, I was forced to put aside the coat of a simple soldier, and I found myself at a loose end in Epinal, leading the life of a divisional interpreter. ${ }^{4}$

If only I were not a mere interpreter, but rather in the trenches fighting the Hun with my comrades. This is the unsurprising expression of heroism thwarted. While the sentiment is understandable, what is nonetheless noteworthy here is the clear and unambiguous separation between interpreting and conflict. The shameful passivity that Maze, Maurois and Hansi all note - shameful because it removes them from the field of valour - stems directly from the enforced separation between the role of the interpreter and that of the soldier and conjures in each account a tone specific to the Great War. Yet Maurois', Maze's and Hansi's 
accounts are all quite different declensions of the interpreter's role, and demonstrate different uptakes of the hand they are dealt. ${ }^{5}$ From Maurois to Maze to Hansi, we will see a progressive shift from acceptance to denial: Maurois embraces regret, Maze shrugs it off good-naturedly, and Hansi rejects it outright.

\section{The passive voice}

Maurois and Maze left strikingly different versions of the war, both of which are yet accounts of being isolated from battle. Where Maze plods through a sequential, documentary account, enlivened at times by moments of Boy's Own Adventure, Maurois transforms his lived experience into both a wry, detached fictional meditation, and a memoir. The regret he voices in his Mémoires certainly finds fewer opportunities to redeem itself than that of Maze. Not for Maurois impetuous dashes across the countryside on a motorbike to perform reconnaissance. More than anything, the section of his Mémoires pertaining to the Great War tells of his awakening as a writer. This was not a new impulse for him; quite the contrary.

Au temps de mon enfance et de mon adolescence, j'avais rêvé d'être un écrivain. Ma vie dans les ateliers ne semblait guère favorable à ce dessein. Mais mon espoir demeurait tenace. Pendant mes dernières années de lycée, j'avais composé quelques contes; le régiment m'avait inspiré une longue nouvelle: Gaucher caporal. (Maurois, 1970a, p. 73)

During my childhood and adolescence I had always dreamed of being a writer. My [...] life in the factory scarcely seemed to favour this plan, but my hope persisted. During my last years at the Lycée I had written a few stories; the army had inspired a long novelette, Gaucher Caporal [...]. (Maurois, 1970b, p. 59)

He also mentions writing and attempting to publish a collection of short stories, but self-criticism sees him back away from publication, and he resigns himself to a future running the family business. However the war, and proximity to danger, reawaken the stymied writer.

Le spectacle des troupes qui allaient prendre leurs postes de combat, les têtes s'inclinant au passage des obus comme des blés courbés par le vent, les entonnoirs tout frais qui sentaient la terre et la poudre, éveillèrent en moi un sentiment vif que je n'avais pas éprouvé depuis longtemps: le désir d'écrire. (Maurois, 1970a, p. 119-120)

The spectacle of the troops on their way to take up combat posts, heads bent before the passage of shells like wheat bowed down by 
the wind, shell-holes smelling of earth and powder, awakened in me a keen longing that I had not felt for a long time - the desire to write. (Maurois, 1970b, p. 99)

The spark he describes is highly visual, even painterly, but his nightly conversations with fellow officers at GHQ are the material out of which he spins Les Silences du Colonel Bramble. He eventually sends the finished novel to a young Bernard Grasset, at a friend's suggestion (Maurois, 1970a, p. 131), and his commanding officer gives him permission to publish it, provided he does so under a pseudonym. "Les officiers anglais avec lesquels vous vivez [...] pourraient se reconnaître et seraient froissés. S'il y avait la moindre plainte, c'est encore la malheureuse mission qui serait blâmée" (Maurois, 1970a, p. 132). "The British officers with whom you are living or have lived might recognise themselves and be offended. If there is the slightest complaint it will be this unhappy Mission that will be blamed..." (Maurois, 1970b, p. 110). And so he comes to choose André, in memory of a cousin killed in battle, "et Maurois, nom d'un village proche de Cambrai, parce que j'en aimais la sonorite triste..." (Maurois, 1970a, p. 132). " [...] and Maurois, the name of a village near Cambrai, because I liked its sad sonority" (Maurois, 1970b, p. 110). The writer we now know as André Maurois is born of the conflict.

Of what does Les Silences du colonel Bramble consist? It follows a small cluster of recurring characters during an unspecified period of the Great War: officers in the British Expeditionary Force, for the most part belonging to the Lennox Highlanders; and their interpreter Aurelle, whom we can unproblematically assume to be based on Maurois himself. ${ }^{6}$ The two predominant characters are Aurelle and Docteur O'Grady, who becomes the titular character of the two sequels. However it is reasonable to take Aurelle as the protagonist, and not merely because he is biographically keyed to the author. While there are occasional narrative digressions not featuring Aurelle, the plot follows his movements, not O'Grady's. Furthermore, there are chapters in the first person presented as firstly a letter written by Aurelle, and secondly an extract from Aurelle's diary. The narrative is also interspersed with Aurelle's poetry, which he is sometimes writing during events of the novel.

In terms of plotting, Bramble is the antithesis of A Frenchman in Khaki's plodding sequentiality. The war is ever-present but in the background, punctuating rather than controlling the narrative, and providing a counterpoint against which Maurois spins out tenuouslyrelated vignettes. Some of these involve day-to-day practicalities, such as oganising food and lodgings as they decamp from location to location. Some are narrative digressions or mere anecdotes, unrelated to their present circumstances, recounted by secondary characters.

On one occasion Aurelle is sent as liaison much closer to action than is usual, when telephone lines are cut and he must literally act as a 
Hermes figure, delivering messages between French troops at the front and a BEF command centre. And on another Aurelle is injured by a mortar - at which time a member of Aurelle's regular coterie is killed. Yet even this more calamitous event is secondary to the kind of scene that dominates the novel, namely: lively but aimiable conversations, frequently on the topic of national differences between the French and the English.

As liaison officer, it falls to Aurelle to represent the French. While the British are mostly represented by a combination of English and Scottish characters, Aurelle's most cogent sparring partner is Doctor O'Grady, who is carefully positioned as Irish, and therefore able to engage in debate with a clarity and sophistication denied to the aimiable but doltish Colonel (later General) Bramble and his like. ${ }^{7}$

This opposition between the British and the French is established in the first pages in this exchange between Aurelle and Bramble. The former is surprised at how readily the English will judge a man's intelligence by his sporting prowess.

- Ne croyez-vous pas, sir, que l'intelligence...

- Je hais les gens intelligents... Oh, je vous demande pardon, messiou. (Maurois, 1950, p. 11)

"Don't you think, sir, that intelligence..."

"I hate intelligent people. Oh, I do beg your pardon, messiou.",

The club is almost immediately taken up by Major Parker, who reinforces the opposition between sporting and intellectual pursuits, while at the same time deftly aligning it with national stereotypes .

- Mais ne trouvez-vous pas vous-même, Aurelle, reprit le major Parker, que l'intelligence soit estimée chez vous au-dessus de sa valeur réelle? Il est certes plus utile dans la vie de savoir boxer que de savoir écrire. (Maurois, 1950, p. 12)

"But, Aurelle”, asked Major Parker, “don't you yourself find that intelligence is overrated by the French? It is obviously more useful in life to know how to box than how to write."

It is difficult not to be struck by the resonance here with Maurois' (and Maze's) regret at being excluded from fighting. Intelligence, and its practical application, writing, are set against sport, specifically exemplified by the ability to defend oneself. And Aurelle's association with the indefensible practice of writing (poetry and even, we are told, a doctorate (Maurois, 1950, p. 43) is the subject of repeated consternation in Bramble and $O$ 'Grady. For instance:

- Aurelle, cette fois vous écrivez des vers; vous ne pouvez le nier: vous êtes pris la main encore sanglante. 
- Houugh, fit le colonel Bramble avec indulgence et pitié. (Maurois, 1950, p. 49)

"Aurelle," said the doctor, "this time you are writing verse. There's no denying it - you've been caught red-handed."

"Houngh," said the colonel with a mixture of pity and indulgence.

Aurelle needs not even be seen producing poetry to elicit disgust from his British comrades. A mere (but presumably effete) tendency to embroider a story with descriptive details is enough to raise Bramble's hackles, more than once:

- Ne décrivez pas, messiou, dit le général, c'est très malsain. (Maurois, 1950, p. 186)

"Don't describe them, messiou," said the general, "it's quite unwholesome."

- Messiou, dit le général, no description, please. (Maurois, 1950, p. 188 , emphasis in the original)

"Messiou," said the general, "no description, please."

Even his most intelligent interlocutor, le docteur O'Grady, accuses him of hiding in fiction and living vicariously ("Aurelle qui oublie la guerre en lisant Tolstoï" (Maurois, 1950, p. 123). "Aurelle who loses himself in Tolstoy and forgets about the war.") shortly before Aurelle is wounded in a mortar attack - not in battle, but in the middle of the group's usual dinnertime banter, during which Aurelle pens these lines:

Croyez pas que je moralise,

Si je vous envoie ces bobards,

C'est que notre mess analyse

Ce soir la question du hasard... (Maurois, 1950, p. 134)

Don't think I've turned philosopher

Because I'm sending you tall tales;

But tonight, you see, our Mess Hall's

Debating whether chance prevails...

The ellipsis represents the arrival of the first mortar. While the colonel, major and doctor head out to investigate, Aurelle remains behind with the padre to "rimailler" [to pen bad poetry, to scratch out doggerel]: he receives a shoulder injury from the second mortar; the Padre is killed on the spot. Colonel Bramble is most sympathetic, collecting a stray scrap of poetry "soigneusement" [carefully] and slipping it into the injured interpreter's pocket "avec respect" [respectfully] (Maurois, 1950, p. 135). The seriousness of the moment appears to overturn the colonel's usual disdain for his interpreter's literary inclinations. At the same time, might we see a parallel reversal in Aurelle's (and indeed the narrator's) choice 
of words? His usual activity of poetic composition shifts into poetastery; the verse itself approaches doggerel, and begins to echo O'Grady's judgement about evading the war through fiction. This shift in tone is so self-conscious that it is difficult not to read it as a mise-en-abyme of the writing of the novel - "[...] je vous envoie ces bobards" (Maurois, 1950, p. 134, my emphasis) [I'm sending you tall tales] - and an instantiation of the regret to which Maurois gives more explicit voice in his Mémoires, many years later.

While Maurois seems to have spent a great deal of his time at the front writing, it is an idle pursuit. Unlike Maze, whose painterly abilities are put to use in the field, Maurois cannot boast of such a stretching of his role. In addition to Bramble, he composed and translated poetry (including Kipling's "Kim", which is included in Bramble), and cotranslated a monograph with a comrade, so it is clear that Maurois was, at some level, detached from the war. It is therefore not surprising to find regret - the regret of his Mémoires - encoded in his fiction. Maurois does claim in his Mémoires that Bramble was much appreciated by his comrades in arms, and this in understandable; but it had no strategic value. ${ }^{9}$ Nor is it surprising that regret and self-admonishment should be triggered by the paradigm (translation, literature, poetry, intellect) that has been so carefully aligned with interpreting, and against combat.

\section{The detached observer}

The painter Paul Maze was born in France and died in England, where he married, settled and spent most of his life after serving in the Great War. He was a friend and artistic mentor to Churchill, who agreed to write the introduction to Maze's memoir. This introduction anticipates Maze's regret, which Churchill can hardly presume to assert in the third person. He anticipates and defuses it, beginning with an implicit apologia which would seem unwarranted and impertinent were it written for a fighting soldier.

The author of this vivid book has good right to tell his tale. M. Paul Maze had a close and prolonged view of the fighting front. He saw it with French eyes from the English staff. He was a sous-officier who was the friend of generals. He was a liaison officer without a commission. He was a conscript whose physique and health denied him at the outset his right to serve, but who nevertheless was always to the end among the shells and bullets. (Maze, 1934, Introduction, para. 1)

Churchill places his friend in proximity to peril, and there is some truth to this. Maze has plenty of physical activity, initiative and derring-do to recount in his memoir. Yet for all that he is "among the shells and 
bullets", Maze is not a fighting soldier. Thus Churchill frames Maze's role, and story, as that of the painter-observer whose "close and prolonged view of the fighting front" was nonetheless a view, and not a first-hand encounter. Distance brings insight, Churchill implies, when his next sentence develops the idea of Maze's view of the front as one of detachment. His "French eyes", seeing as they must from a different perspective, had something new to tell. The rest of this paragraph extends the trope of displacement and outsider status, which returns later in other terms:

[his] status was thoroughly nondescript (Maze, 1934, Introduction, para. 2)

He was unique and indefinable [...] (Maze, 1934, Introduction, para. 2)

[...] this anomalous figure, neither French nor English, neither officer nor soldier, nor indeed civilian [...] (Maze, 1934, Introduction, para. 5)

However Churchill is quick to reassert the controlling metaphor of the painterly gaze, and marry it with Maze's role as interpreter. "[H]e was an artist of distinction [who] could record impressions with revealing fidelity", writes Churchill (Maze, 1934, Introduction, para. 3 - my emphasis). This reads as a general evaluation of the painter's skill with the brush; but it is more. Maze was an interpreter with a broad remit ("My duties were to help and gather any information I could for Corps Headquarters.", p. 119) whose talent as a painter was put to tactical use.

Early in the spring General Gough sent for me and instructed me to proceed to the 2nd Army in the north to make a series of drawings, taking in the battle fronts of Messines and Wytschaete. (Maze, 1934, p. 128)

My work was very interesting. Bit by bit we dissected the ground with our field-glasses, and I made drawings from every possible angle, marking every obstacle which could hinder the advance of our troops. In order to show these more effectively, I imagined myself looking on to our own lines from the German side. (Maze, 1934, p. 130)

I helped him with maps which covered an area that had nothing to do with the country I had come from. (Maze, 1934, p. 131)

The painterly gaze that so interests Churchill is not just skilled; it is revealed here to be fluid and incorporeal too, able to move freely around entrenched positions. These extensions of his role as interpreter rely on 
the detachment and displacement Churchill observes. Yet Churchill also explains that "his 'seeing eye' and recording notebook brought back calm, trustworthy, lucid and increasingly experienced information" (Maze, 1934, Introduction, para. 4). The fidelity and trustworthiness of Maze's information connect his detachment to a certain predictable view of the interpreter's role. These characteristics accrete neatly into an untroubled paradigm of the interpreter at work - all-seeing, unbiased and transcending borders - even when the work performed has little to do with interpreting.

So unquestioned is that trustworthiness that it serves to extricate him from the suspicion of spying. ${ }^{10}$ Separated from his unit and overheard speaking to German prisoners in German, his third language, Maze is immediately arrested. Only the fortuitous encounter with an officer who can vouch for him as company interpreter garners his release: Maze's status as interpreter thus serves to emphasise his integrity, rather than his untrustworthiness.

There are two points worth underlining in this story: both will frame my reading of Hansi's memoir. The first is self-evident: the more the interpreter is detached from fighting, and thus from contact with the enemy, the less call there is for suspicion. An interpreter whose primary function is to act as liaison officer between allies is by definition both detached from combat and from reasonable suspicion of spying. ${ }^{11}$ The second goes to the figurative power of the interpreter, and echoes the rhetorical move Churchill makes in his preface, remarking upon Maze's "fidelity" and "trustworthiness" even when the latter steps out of the more narrowly-defined role of interpreter. Note that when the interpreter extends himself beyond mere interpreting, this particular trope is mobilised to recuperate his other activities under the umbrella of interpreting and thereby legitimise them.

Neither Maze nor Maurois, in spite of their various extra-curricular activities, ever has any serious engagement with the enemy nor really challenges the shield wall between interpreting and fighting. Hansi, we will now see, takes a very different approach, engaging the enemy and in so doing dismantling that separation as he declines, then embraces, the interpreter's role.

\section{The active voice}

A travers les lignes ennemies. Trois années d'offensive contre le moral allemand is an account by two interpreters of their experiences during the Great War. The first is Hansi; the second, his colleague Ernest Tonnelat. The preface to their volume was written by Hansi alone, and in the first person. It opens with the expression of regret cited earlier, which I give now in a fuller context. 
J'ai dû, avec regret, abandonner la capote du simple soldat, et je menais à Epinal la vie un peu désœuvrée d'interprète de la place. Quelques interrogatoires de prisonniers, des rapports à faire au général, étaient les rares travaux intéressants qui apportaient quelques diversions à la paperasserie d'un 2e bureau d'état-major de division. Je voulais faire plus; je voulais me rendre compte de la mentalité de cette Allemagne en guerre; je voulais l'étudier, la connaître, comme j'avais connu l'Allemagne d'avant-guerre. (Hansi \& Tonnelat, 1922, pp. 7-8)

With regret, I was forced to put aside the coat of a simple soldier, and I found myself at a loose end in Epinal, leading the life of a divisional interpreter. An occasional prisoner interrogation or report to the general were the rare interesting diversions from the paperwork of a Second Bureau of Divisional Headquarters. I wanted to do more; I wanted to understand the mentality of this Germany at war; I wanted to study it, to know it, as I had known pre-war Germany.

Hansi is certain he can do more, concluding that the confidence of the German army is founded on what he contrues as the obvious lie that the French were the belligerent party in the conflict, and that the Germans had moral right on their side. The Allies must therefore counter lies with truth, by which he means propaganda, and more specifically something better than the clumsy attempts he notices being used at the time.

Car la condition première, fondamentale, d'une bonne propagande est celle-ci: il faut, si l'on veut agir sur l'ennemi, écrire sa langue aussi bien que lui; la moindre faute rend ridicule et annule l'effet d'un papier par ailleurs bien conçu. (Hansi \& Tonnelat, 1922, p. 10)

For the most basic prerequisite of good propaganda is the following: one must, if one wishes to influence the enemy, write his language as well as he does; the smallest error sounds ridiculous and negates the effect of an otherwise well-conceived document.

When he tries his hand at a more skillful version, his superiors are impressed enough to send him to the new "bureau de propagande qui venait d'être créé au ministère de la Guerre" (Hansi \& Tonnelat, 1922, p. 11) [propaganda office that had just been created within the Ministry of War]. This is where he meets Tonnelat, another officier interprète. Together, they become the nucleus of the new bureau, responsible for "la besogne assez lourde de la rédaction, de l'impression et de l'expédition des tracts" (Hansi \& Tonnelat, 1922, p. 14) [the rather difficult task of writing, printing and delivering tracts]. In 1916 they are joined by a third officier interprète, Raymond Schuhl, thus putting no fewer than three interpreters at the heart of the new propaganda bureau. 
The bulk of the book is made up of descriptions of the various techniques they employed: simple counterfeit; reproduction and dissemination of authentic documents written by disaffected Germans and hopeful republicans; flagrant parodies of pro-German Alsatian newspapers; re-publication of accurate transcripts of Allied documents which had been deceptively edited by the Germans for the consumption of the German public; hijacking of enemy propaganda. In all of these the particular skill set of the three interpreters comes into play: native speaker-like competence, and bi-culturality, in the first instance. ${ }^{12}$ But beyond the desire to avoid stylistic clumsiness ("la moindre faute rend ridicule" - the smallest error sounds ridiculous), there is the more significant matter of énonciation: certain declarations will not ring true if they are addressed to the Germans from their enemy.

Mais tous les arguments que je pouvais exposer à un Boche de 1914 étaient absolument inefficaces; tout ce que leur disait un Français - un ennemi - était tout à fait inopérant; car c'était pour eux un article de foi qu'un Francais ne pouvait débiter que des mensonges, qu'un journal français ne pouvait imprimer que des faussetés. (Hansi \& Tonnelat, 1922, p. 8)

But any argument I might have put to a Kraut in 1914 would have been pointless: anything a Frenchman, their enemy, said to them was completely ineffective, because one of their articles of faith was that a Frenchman could only spout lies, and that a French newspaper could only print falsehoods.

In other words, allied propaganda is effective insofar as it manages to brand itself as authentic. We might call this a variation on the tactic of translational invisibility.

In the case of Hansi, a further skill complements the others, that of the artist. In various instances of hijacking and rebranding of German propaganda, Hansi undermines not only the text but also the iconography, adding touches to transform a German helmet into a chamber pot; or John Bull about to be crushed by the combined might of the German people, into Kaiser Wilhelm. Tellingly, he calls this "camouflage" (Hansi \& Tonnelat, 1922, p. 73).

As the war progresses and moves into its final stages, there are no longer enough available planes to air drop the considerable output of the propaganda office across enemy lines. Hansi pays a visit to his old friend Clemenceau, at the time Prime Minister and Minister of War, who is sufficiently impressed with the account of the bureau's activities and outcomes to send Hansi straight to Général Pétain, who in turn convenes a meeting at his HQ so that Hansi can brief relevant section heads on the bureau's needs (Hansi \& Tonnelat, 1922, pp. 154-55). It is at this point that "l'artillerie de la propagande" [propaganda artillery unit] is born (Hansi \& Tonnelat, 1922, p. 156), using long-range cannons, rather than 
aircraft, to deliver their "mitraille intellectuelle" (Hansi \& Tonnelat, 1922 , p. 158) [intellectual gunfire]. They speak of "grenades lancetracts", "obus lance-tracts" and "engins lance-tracts" (Hansi \& Tonnelat, 1922, p. 156, p. 161) [tract-launching grenades, shells and devices] and their obvious pleasure in word-play - note in particular "feuille volante" (Hansi \& Tonnelat, 1922, p. 17) and "bons à tirer" (Hansi \& Tonnelat, 1922 , p. 158$)^{13}$ - betrays a smug satisfaction at having moved beyond regret to find a new form of offensive.

From their early declaration that the Germans had to be beaten at their own game, as much in this arena as in every other ("Mais ils devaient, là comme partout ailleurs, être battus avec leurs propres armes" (Hansi \& Tonnelat, 1922, p. 14) ), they arrive at the most literal possible weaponisation of language, transforming "le petit bureau du ministère" [this little bureau within the ministry] into "une grande machine de guerre" (Hansi \& Tonnelat, 1922, p. 12) [a great war machine]. The Germans themselves recognised that propaganda was as damaging as ordnance. Hansi and Tonnelat cite an open letter from Hindenburg to the German people on 2 September 1918 drawing an extended, explicit parallel between the two, "feu roulant d'artillerie" [a barrage of artillery fire] on the one hand and "feu roulant de papiers imprimés" [ a barrage of printed tracts] on the other (Hansi \& Tonnelat, 1922, pp. 177-178). These are "flèches empoisonnées" (Hansi \& Tonnelat, 1922, p. 178) [poisoned arrows].

It is a measure of how effectively those poisoned arrows are hitting their target that Hindenburg himself is compelled to make the invisible visible. Certainly Hansi and Tonnelat take some pride in pointing out their own success. ${ }^{14}$ Moreover, they conclude that the success of their own propaganda, as opposed to the enemy's, lies in the realm of higher truth. As long as the Allies had truth and righteousness on their side, the Germans would never be able to "faire la critique du régime politique pratiqué par ses adversaires occidentaux" (Hansi \& Tonnelat, 1922, p. 189) [mount a critique of the system of government practised by their Western adversaries].

La propagande française, au contraire, a vite discerné le point faible de l'armature morale de l'adversaire et elle s'est faite l'interprète du désir de liberté politique que portaient en leur cœur, quoi qu'on en ait dit, bon nombre d'Allemands. (Hansi \& Tonnelat, 1922, p. 189)

On the contrary, French propaganda rapidly identified the weak spot in the enemy's moral scaffolding and made itself the interpreter of that desire for political freedom that so many Germans, in spite of what might have been said, nurtured in their hearts. 
Se faire l'interprète de quelque chose might be a common expression, but its use here is not merely fortuitous. By mapping interpreting onto propaganda, they are indeed constructing the unidirectional dissemination of tracts as an act of mediation: eavesdropping on the good people of Germany, slaves to a corrupt dynasticism, they translate their desires into material form, and enunciate those desires in the very voice of the German people, effacing themselves as interpreters should. Not only are our interpreters insisting on their invisibility, but also inferring their absolute, unproblematic fidelity.

Thus the radical disruption of their narrow roles as interprètes officiers de liaison comes full circle. Moving far beyond the remit of the interpreter, they construe their new job description retroactively as the natural extension of the former. The initially perceived divorce between interpreting and combat is neatly collapsed through the figurative power of the interpreter. This is the interpreter as soldier; this is interpreting as an act of warfare; this is regret purposefully redeemed. But here no-one is betrayed, for the trope of the interpreter - truthful, self-effacing, a mere conduit for that which the German people believe in their hearts confirms, in turn, the moral rectitude of their positions.

The logic is entirely circular, and predicated on the assumed fidelity of the interpreter: if their communications are accurate representations of what Good Germans believe in their hearts, then they are faithful interpreters; if they are faithful interpreters, then what they have "heard" must be accurate; if so, then they are morally right, as indeed they have previously asserted.

The separation between interpreting and combat which underpinned all of these accounts at the outset is, as we have seen, undone impressively by Hansi and Tonnelat; yet they would still recuperate their extracurricular activities under the metaphorical umbrella of the interpreter's work, as though maintaining a separation between interpreter and soldier. This rhetorical move relies crucially on a concept of betweenness uncontaminated by partisanship, a fiction of neutrality entirely at odds with their subordination to their military superiors. ${ }^{15}$

Yet that subordination is a constant of the military interpreter's life, then as it is now. What gives these accounts a tone particular to the Great War is the sentiment of regret that frames them all, and the impulse to heroism that underpins it. It is hard to imagine the military interpreter of today, familiar as she is with combat and its attendant dangers, given to such wistfulness.

\section{References}

Baker, C. \& Tobia, S. (2012). Being an interpreter in conflict. In H. Footitt \& M. Kelly (Eds.), Languages at war: Policies and practices of language contacts in conflict (pp. 201-221). London: Palgrave Macmillan. 
Beach, J. (2008). Intelligent civilians in uniform: The British Expeditionary Force's Intelligence Corps Officers, 1914-1918. War \& Society, 27(1), 1-22.

Cowley, P. (2015). Dans son propre langage: Louis Guilloux, interprète mauvais genre. In T. Do, V. Duché \& A. Rizzi (Eds.), Mélanges: Festschrift pour Anne Freadman (pp. 405-421). Paris: Garnier.

Delisle, J. \& Woodsworth, J. (2012). Translators through history. Amsterdam: John Benjamins.

Gaiba, F. (1998). The origins of simultaneous interpretation: The Nuremberg Trial. Ottawa, ON: University of Ottawa Press.

Guilloux, L. (1978). Carnets : 1921-1944. Paris: Gallimard.

Guilloux, L. (1976). Salido, suivi de O.K., Joe ! Paris: Gallimard.

Guilloux, L. (1982). Carnets : 1944-1974. Paris: Gallimard.

Hansi, \& Tonnelat, E. (1922). A travers les lignes ennemies : Trois années d'offensive contre le moral allemand. Paris: Payot.

Heimburger, F. (2014). Power relations in postcards of French First World War military interpreters. In M. Wolf \& A. Fernández-Ocampo (Eds.), Framing the interpreter: Towards a visual perspective ( $\mathrm{pp}$. 96-105). London: Routledge.

Inghilleri, M. (2010). You don't make war without knowing why. The Translator, 16(2), 175-196.

Maurois, A. (1950). Les silences du Colonel Bramble. Les Discours et nouveaux discours du Docteur O'Grady. Paris: Grasset.

Maurois, A. (1970a). Mémoires. 1885-1967. Paris: Flammarion.

Maurois, A. (1970b). Memoirs. 1885-1967 (Denver Lindley, Trans.). London: Bodley Head.

Maze, P. (1934). A Frenchman in khaki. London: Heinemann.

Roland, R. (1999). Interpreters as diplomats: A diplomatic history of the role of interpreters in world politics. Ottawa, ON: University of Ottawa Press.

Russellkurt80. (2013, August 8). Paul Maze interviewed about Winston Churchill [Video file]. Retrieved from https://www.youtube.com/ watch? $=$ =cvD_B_mczCs

Tymoczko, M. (2003). Ideology and the position of the translator. In what sense is a translator 'in between'? In M. Calzada Pérez (Ed.), Apropos of Ideology. Translation Studies on Ideology - Ideologies in Translation Studies (pp. 181-201). Manchester: St Jerome.

1 Within conflict zones, as Inghilleri points out, the interpreter's ethical decision-making and ability to function impartially are subordinate to military command structures and loyalty to comrades in arms (Inghilleri, 2010, p. 179, p. 185). 
2 This presents interesting analogies to the case of Louis Guilloux, who wrote of his experiences working as an interpreter for the Americans in the final stages of WWII. His contemporaneous diaries later became the novel O.K., Joe. See Cowley 2015.

3 I exclude the much later sequel, Nouveaux discours du Docteur O'Grady, published in 1947 — incidentally the year Herzog legally becomes André Maurois. While the characters of Aurelle and O'Grady are still present, it is set in a civilian context after World War Two, and Aurelle is no longer an interpreter.

4 All translations from Hansi and Tonnelat (1922) are my own.

5 In contrast to the narrative accounts studied here, Heimburger (2014) explores the use of staged portrait photographs as a strategy used by "First World War interpreters [...] to come to terms with their particular position", notably their isolation from their French comrades in arms, and the accusation of embusquage [shirking] (pp. 96-97).

6 Maurois' Mémoires make the similarities very clear. Moreover, by the third book in the series (Nouveaux discours du Docteur O'Grady), Aurelle begins making explicit first-person references to being the author of Maurois' written output, as for instance in this reference by Aurelle to one of Maurois' early science fiction efforts: "L'idée de l'île évoqua deux personnages que j'avais imaginés jadis pour le Voyage au pays des Articoles [...]” (Maurois, 1950, p. 391) [This island idea brought up two characters I had once imagined for my Voyage au pays des Articoles.]

7 O’Grady has an almost Swiftian line in satire.

8 All translations from Bramble and its sequels are my own.

9 He also describes the praise and recognition he received from Maréchal Lyautey, Douglas Haig, Georges Clemenceau and even Rudyard Kipling.

10 A late interview with him, available on youtube, shows a man with only an occasional, barely perceptible trace of French inflection in what would otherwise pass for native English. We cannot know if he passed quite so easily as English in his younger years. Certainly, when he recounts his arrest as a suspected spy for speaking with Germans, at the beginning of his war service, “[t]hey couldn't make out what I was” (Maze, 1934, p. 41). But this has as much to do with appearance as it does with language, as he makes clear later when he decides to enlist officially with the French army in order to be formally (and visibly) kitted out as an interpreter and to put paid to any residual suspicion (Maze, 1934, p. 58). Until that point, Maze had served in a less formal capacity, on the basis of a letter of introduction from the British Consul, an acquaintance of his (Maze, 1934, p. 9). 
11 Beach reminds us that in early 1915 "the interpreting function for the BEF was taken over by the French army". Previously, a great number of officially designated interpreters in fact belonged to British military intelligence. That shift goes some way towards explaining why the trope of the spy is almost non-existent is these three accounts (Beach, p. 5). Curiously, however, much of Maze's account does in fact correspond to a commonly held perception of the Intelligence Corps in 1914, cited by Beach: "chaotic improvisation, inexperienced personnel whizzing around on motorcycles and a sense of useful anarchy" (Beach, 2008, p. 4). Of further interest is Baker and Tobia's examination of the training of British military interpreters in World War Two, in which they note that learning to ride a motorbike was as crucial to the interpreter's skill set as was learning how to perform consecutive interpreting (Baker \& Tobia, 2012, pp. 213-214).

12 Later, when they are required to produce material for the eastern front, they bring in experts in the Slavic languages, recognising that: 'L'Allemagne et les façons de penser allemandes nous étaient assez familières; mais nous avions conscience d'être mal préparés à parler à des Slaves." (Hansi \& Tonnelat, 1922, p. 162) [Germany, and German ways of thinking, were familiar enough to us, but we were conscious of being ill-equipped to speak to Slavs.]

13 These two terms are more problematic to translate. "Feuille volante" is a play on loose leaf paper and flying paper. "Bons à tirer" are final proofs, but here the expression plays on "tirer" (to print, but also to shoot) to produce something like ready to shoot.

14 They speak of their efforts as having "empoisonné l'arrière de l'armée allemande et inspiré à Hindenburg cet appel angoissé qui fut notre plus grand succès" (Hansi \& Tonnelat, 1922, p. 12). [poisoned the German rear army and prompted Hindenburg to make his anguished appeal which was our greatest success].

15 Tymoczko (2003) most helpfully spells out the conceptual foundations of the idea of betweenness, that underpin the image of the interpreter or translator as a conduit, and at the same time elide questions of ideological implication. 